\title{
Colonial Architecture in Panama City. Analysis of the Heritage Value of Its Monastic Buildings
}

\author{
Antonio Cubero Hernández ${ }^{1, *(1)}$ and Silvia Arroyo Duarte ${ }^{2(1)}$ \\ 1 Department of Urbanistic and Land Management, Higher Technical School of Architecture, \\ University of Seville, 41004 Sevilla, Spain \\ 2 Departamento de Arte, Facultad de Arquitectura y Diseño, Universidad de Panamá, Panama City, Panama; \\ silvia.arroyo@up.ac.pa \\ * Correspondence: a.cubero@outlook.com
}

Received: 17 November 2020; Accepted: 18 December 2020; Published: 21 December 2020

\begin{abstract}
The Historic District of Panama City was inscribed on the World Heritage List in 1997 for representing an exceptional example of 17th century colonial urban planning in the Americas. This article focuses on the specific analysis of the deteriorated monastic typology, highlighting its historical role as an articulating piece of the original urban layout designed in 1673 after the transfer from Panamá Viejo to the current location and which continues today. Our methodology consisted of reviewing the different stages of each of these buildings, extracting common events, and identifying the examples of the greatest value loss, with the aim of enhancing and highlighting their historical footprint. This study includes approaches from urbanism, architectural history, and heritage preservation that allows us to discuss possible tools, either for protection or adaptative reuse, to avoid the deterioration of such important historical heritage.
\end{abstract}

Keywords: Panama; monastic buildings; World Heritage; historical district; colonial architecture

\section{Introduction}

The Republic of Panama is in the center of the American continent, connecting North America and South America. Cooke and Sánchez [1] (p. 3) explain that it serves as a bridge or corridor between these great masses and influenced the spread of people, agriculture, and technology, which it continues to do to this day. The first settlement of the city in modern times is known today as the archaeological site of Panamá Viejo. It was the first city founded in 1519 by the Spanish in the American Pacific, near an indigenous fishing village. Today, it is an archaeological site in the middle of a growing modern city. In 1671, Henry Morgan and his pirates attacked the city by land, arriving from the Atlantic. That place was burned, destroyed, abandoned, and used as a quarry for the construction of the new settlement to the west, known today as the Historic District of Panama City, the case study of this article.

According to its "Retrospective Statement of Universal Value" [2], the city moved near the Ancón Hill looking for higher quality resources in 1673. It was strategically located in a peninsula that was easier to defend and "closer to the islands that were used as the port and near the mouth of a river that eventually became the entrance of the Panama Canal" [2] (p. 2).

Today, the Historic District of Panamá is a "unique blend of 19th and early 20th century architecture inspired by late colonial, Caribbean, Gulf Coast, French, and eclectic but mostly Neo-Renaissance styles. In the 19th and early 20th centuries, building styles evolved significantly, but spatial principles were fundamentally preserved" [2] (p. 3). 
The Historic District has a regular layout with rectangular blocks, not of equal size, a central plaza, and the remains of Italian design fortifications that represent "an exceptional and probably unique example of 17th century colonial town planning in the Americas" [2] (p. 3). These relevant features are the tangible effect of the Transisthmian route that crosses from the Atlantic to the Pacific, that eventually developed into a railroad and then the Panama Canal.

\section{Panamanian Monastic Buildings}

For centuries, colonial religious architecture has played an important role in the configuration of the urban layout of European cities. This was intensified during the counter-reformation period, especially in Spanish cities, that saw the growth of religious orders since the middle ages and their strengthening through the 17th century. By that time, the convents had an enormous presence in the center of the cities, occupying the interior of the walled enclosures [3] (pp. 1-3). The same happened in Latin America [4] (p. 13) and Panama.

In this study, we will focus on the Panamanian colonial religious architecture and its evolution throughout its more than five centuries of history. It is convenient to justify the choice of religious typology as a case study in contrast to the other two main colonial architecture typologies that have survived to this day: civil and military [5] (p. 87). This is based on this typology's unique or outstanding values of monumentality and scale within the urban footprint and how they affect the understanding of the heritage of the Historic District of Panama, declared World Heritage by UNESCO in 1997 [6]. Most of the religious buildings that have survived to this day have the highest protection both nationally (National Historic Monument) and internationally, which proves the importance of the conservation of these buildings.

On the other hand, the role that religious communities played in Panamanian society is highly relevant from various perspectives. As small cities within the city, they were strategically located both in Panamá Viejo near the main square and in the Historic District, protected by the wall. Here, they served as a point of control and defense, as they are also structures protected by perimeter fences [7] (pp. 72-73). In addition to their own ecclesiastical and oratorial use, they welcomed the most needy, generated work in their gardens, kitchens, and stables, and from an intellectual perspective, they were the precursors of science and education, founding the first university in the country.

Today, only five churches (including the Cathedral) remain within what was the intramural enclosure. In that original formation of the city, the impact of religious architecture on the urban layout was much greater, since they were monastic complexes made up of cloisters and orchards, which have deteriorated and in some cases entirely or partially disappeared, while some remain in a dilapidated state. The redefinition of that urban footprint and its connections with the present will give us clues about the heritage gains and losses of these historic complexes.

\section{Pre-Existences in the City of Panamá Viejo (1519-1671)}

As a starting point, we must travel to the early 16th century, in the middle of the Spanish colonization of America, when the first conquerors arrived at the Isthmus of Panama. This conquest was characterized not only as military, but also religious-linked to evangelization or catechizationestablishing language and political institutions. All this involved the construction of churches, convents, and monasteries in each of the colonies.

In Panama, the first religious community to take root was the Franciscans, with the founding of their modest monastery in Santa María la Antigua del Darién, the first colony founded in Panamanian territory in 1510 by Vasco Núñez de Balboa. Here, the first diocese of both the isthmus and the continent was created and the first cathedral was built at the request of the Spanish Crown in 1513 [5] (pp. 149-151). However, it did not last long, since the city of Panamá Viejo was founded in 1519, assuming the transfer of all institutions-including the Episcopal— to the new city. 
Recent research [8] presents a hypothesis about what the first layout of Panamá Viejo could have been. It is easy to imagine or deduce that the first thing that was drafted was the main square, which is completely eccentric. As the objective of Panamá Viejo was to be a port city looking for a connection with the Pacific Ocean, to the south of the square, the city was designed with the port to the northeast and a hill to the southeast. There, they envisioned the construction of the foundry house and the fortress. Space for growth was left towards the north-to a lagoon-and the west. One of the first convents, Nuestra Señora de la Merced, was built towards the west starting in 1522 and its permanent construction in 1540.

Therefore, it is entirely possible that the first section of the Panamanian urban layout was formed by a rectangle from the main square to the La Merced, through Calle de la Carrera-the first street running south to north, drawn west-east and parallel to the coast of the Pacific Ocean. It is possible that the eastern boundary of the rectangle was the primitive Santo Domingo. These pre-existences and initial outlines will be fundamental in understanding the later constructions. On the cartographic outline of Panamá Viejo, we have identified the location of eight religious complexes (Figure 1).

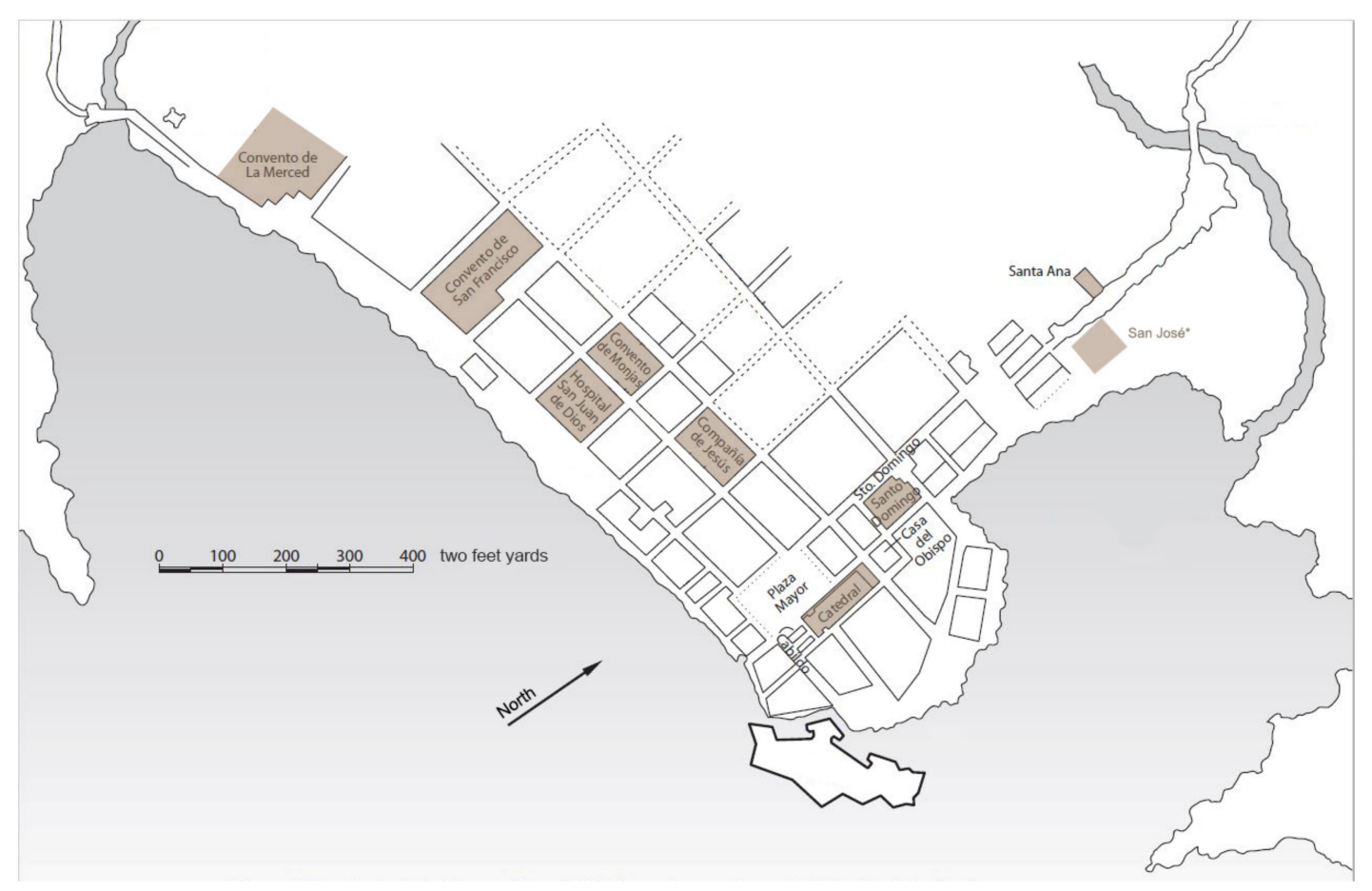

Figure 1. Location of religious buildings in Panamá Viejo, including San José. Figure edited by the authors from the Plan of Panama City in 1609, based on Cristóbal de Roda cartography [9].

\section{Transfer to the Current Historic District of Panama (1673-1821) and Urban Footprint}

In 1673, the city was transferred by royal order to what we know today as the Historic District of Panama. According to García de Paredes [7] (pp. 64-81), the layout was designed by Don Antonio Fernández de Córdoba, and the plots were distributed by the Bishop, Don Antonio de León. The latter secured the area for the Cathedral and the religious orders. By 1675, the Cathedral and the convents were not finished, although in "decent state". The construction was rather slow because it depended on charity.

It is important to highlight how the transfer from the old to the new city entailed certain continuity in the original footprint of the buildings as an analytical value of this study. As Tejeira Davis mentions [10] (pp. 28-30), a decision was made to position all the convents within the walled enclosure with large lots similar in scale to those they had had in the old city. 
The walled enclosure consisted of about 19.5 hectares. However, if we exclusively analyze the surface of the designed plots, we can say that religious use accounted for around $25 \%$ of the Historic District subdivision (3.5 of $14.5 \mathrm{ha}$ ). The same amount of the surface is occupied by religious use in Barcelona and similar in other Spanish cities [3] (pp. 1-3).

As we have mentioned previously, not much remains of that religious architecture in the urban layout of the city, and we wanted to capture it in the same way at a cartographic level in order to extract the useful area of religious buildings that still exist today (Figure 2).

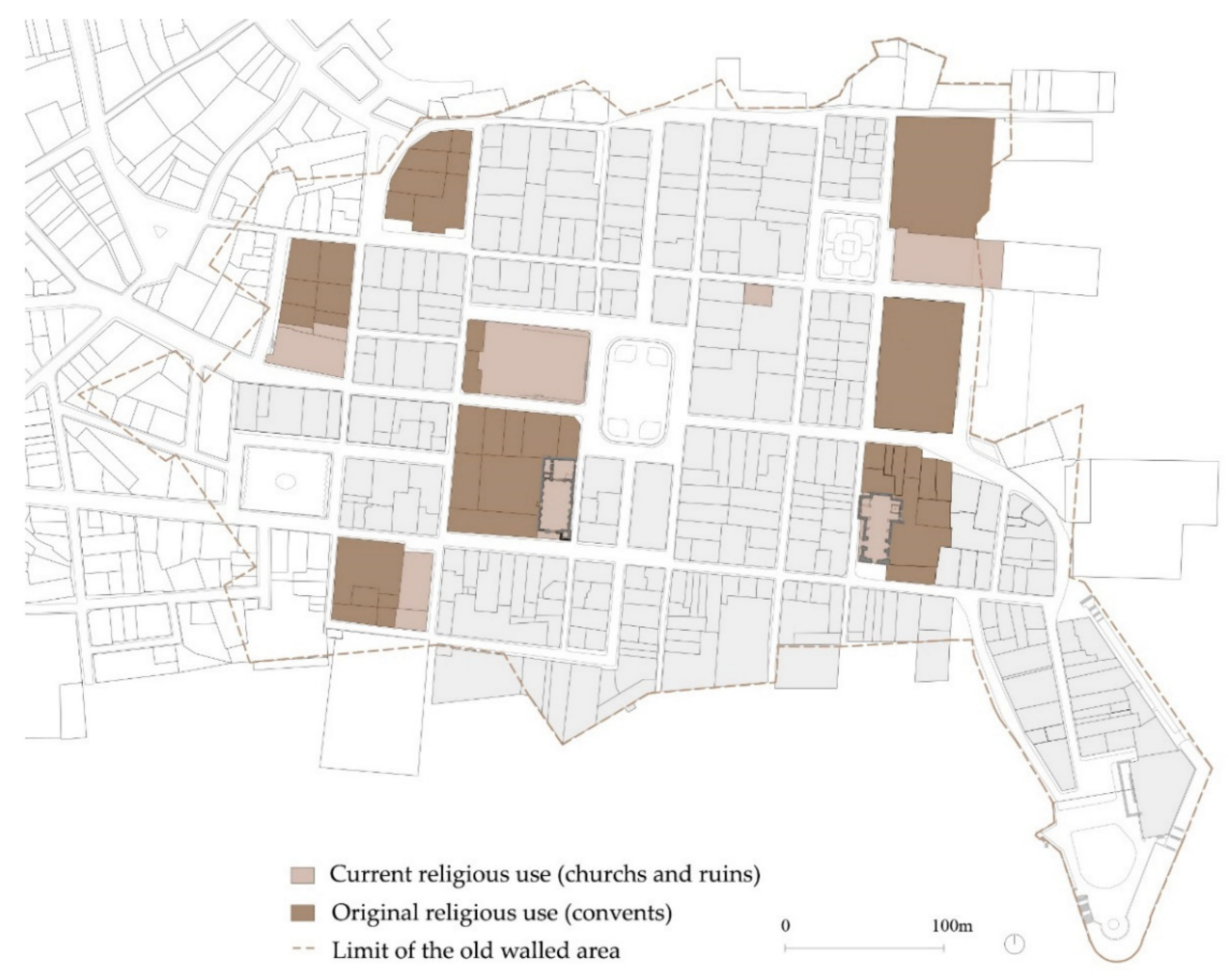

Figure 2. Comparison between the original monastic surface [11] (pp. 96-105) and the current situation in the Historic District.

Of that $25 \%$ (3.5 ha approx.), only $5 \%$ is still preserved for religious use (increasing to $7 \%$ if we consider the existing remains of Santo Domingo and Compañía de Jesús), which has meant a loss of three-fourths of this heritage. Even though there has been a great amount of loss in use, the massive volume of some of the monastic buildings still can be perceived as part of the layering of the Historic District.

\section{Gradual Disappearance of the Monastic Complexes. From Fires to the Expulsion of the Orders}

It can be said that religious architecture in Panama has a common history. In the first place, the buildings were all devastated by the great fires of the 18th century, which ruined a large part of the existing structures, mostly made of wood, and which involved continuous reconstruction attempts. Of these fires, that of 1737 was the most devastating. 
Secondly, in 1821, with the independence from Spain and the union with Gran Colombia, the Colombian government began promulgating a law that abolished all those convents and monasteries that did not have at least eight active religious. It later established a decree in 1857 which declared all religious buildings "dead hand goods", forcing them to be confiscated [12] (pp. 33-37). This marked the end of the religious orders in the area, who chose to leave and abandon the buildings.

This process was similar in other countries, especially in Spain. The same process of State-mandated confiscation of religious buildings took place there, through the so-called Disentailments and Confiscations (Mendizábal, Espartero or Madoz), auctioning and converting them for a variety of new uses. Among these, military use would stand out due to the experience of precedent wars during the French Invasion of Spain in the 19th century [13] (p. 283).

Since the birth of the Republic of Panama in 1903, institutional needs began to emerge that made it necessary to set up new headquarters. Several of the examples that we will study below of buildings of religious origin were or have been converted into public buildings, whether administrative or cultural.

This is an identical replica of the case of Spain after the 1978 Constitution and the emergence of the new regional or autonomous entities. In a previous case study, we analyzed one hundred buildings proposed for institutional reuse in the city of Seville (one of the most important religious architecture cities in the world [14] along with Rome or Lisbon) in the 1980s, among which there were thirteen convents and monasteries [15].

\section{Case Studies}

The methodology to select the cases of study, consisting of a bibliography-supported review of the history of each of the properties, was carried out, from its origin in Panamá Viejo to the present, including the changes in use and its current degree of protection. This analysis combines an urbanistic, historical, and heritage preservation approach, which is summarized in Table 1, detailing all the religious buildings of the Historic District of Panama (including Santa Ana for having lasted from Panamá Viejo, despite being outside the old intramural enclosure).

Of the ten buildings identified, eight were present in the old city of Panamá Viejo. We will divide them into four blocks depending on their current status:

- Continuity of use. Religious buildings that were only churches (they had no known monastic use), which have not undergone changes in use over time and continue to function as such: the Cathedral, San Felipe Church, and Santa Ana Church (the latter outside the walls). Their colonial exterior image persists, despite the fact that their interiors have been completely remodeled $(\ominus)$.

- Partial permanence. There is no trace of the monastic infrastructure of the former San Francisco, San José, and Nuestra Señora de la Merced convents. However, the churches are still in operation and in good condition after several restorations $(\bullet)$.

- Archaeological remains in the process of restoration. In the cases of Santo Domingo or Compañía de Jesús, part of the complex still exists today in the form of archaeological remains, having been "saved" from total destruction by means of protection tools and conservation/restoration projects, some of which are ongoing today $(\odot)$.

- Total disappearance. Finally, it is necessary to emphasize the Monjas de la Concepción Convent and the San Juan de Dios Church and Hospital in the negative extreme, which have now disappeared. In the first case, there is no trace whatsoever in the urban layout since the National Theater and the Government Palace were built on its remains. In the second case, there is some morphological reminiscence, but the identity has been lost $(\bullet)$. 
Table 1. Analysis of the monastic buildings identified from their foundation to the present.

\begin{tabular}{|c|c|c|c|c|c|c|}
\hline Name & $\begin{array}{l}\text { Panamá Viejo } \\
\text { Found. }\end{array}$ & $\begin{array}{l}\text { Historic District } \\
\text { Found. }\end{array}$ & $\begin{array}{l}\text { Other } \\
\text { Uses }\end{array}$ & $\begin{array}{l}\text { Intermediate } \\
\text { Events }\end{array}$ & $\begin{array}{l}\text { Current } \\
\text { State-Use }\end{array}$ & $\begin{array}{c}\text { Orig. } \\
\text { Plot }\left(\mathrm{m}^{2}\right)\end{array}$ \\
\hline San Francisco Convent & 1573 & 1673 & $\begin{array}{l}\text { 1821-Barracks } \\
\text { 1892-School } \\
\text { 1999-School }\end{array}$ & $\begin{array}{l}\text { 1737/1756-Fires } \\
\text { 1761-Restoration } \\
\text { 1918-Rebuilt } \\
\text { 2003-Extension }\end{array}$ & $\begin{array}{l}\text { Only Church in use + } \\
\text { Government Offices }\end{array}$ & 6011 \\
\hline $\begin{array}{l}\text { Nuestra Señora de la Merced } \\
\text { Convent and Church }\end{array}$ & 1540 & 1680 & - & $\begin{array}{c}\text { 1861-Expulsion } \\
\text { 1963-Fire } \\
\text { 1983-Monks return } \\
\text { 1986/1991/2009-Restorations }\end{array}$ & $\begin{array}{l}\text { Only Church in use + Orphanage } \\
\text { + Museum of La Merced }\end{array}$ & 3543 \\
\hline San José Convent & 1610 & 1675 & - & $\begin{array}{l}\text { 1833-Expulsion } \\
\text { 1898-Monks Return }\end{array}$ & Only Church in use & 3106 \\
\hline $\begin{array}{l}\text { Monjas de la } \\
\text { Concepción Convent }\end{array}$ & 1596 & 1673 & $\begin{array}{l}\text { 1880/1890-Barracks + } \\
\text { Nuns Theater }\end{array}$ & $\begin{array}{l}\text { 1621-Earthquake } \\
\text { 1862-Abandonment } \\
\text { 1905-Demolition }\end{array}$ & $\begin{array}{l}\text { National Theater }+ \\
\text { Government Offices }\end{array}$ & 4136 \\
\hline $\begin{array}{l}\text { San Juan de Dios Church } \\
\text { and Hospital }\end{array}$ & 1575 & 1673 & $\begin{array}{l}\text { 19th Century—“Dalia" } \\
\text { Warehouse }\end{array}$ & 1930_Partial Demolition & School + Private Houses & 2695 \\
\hline Santo Domingo Convent & 1571 & 1675 & $\begin{array}{c}\text { 1857-Partially private } \\
\text { houses }\end{array}$ & $\begin{array}{l}\text { 1737/1756-Fires } \\
\text { 1857-Abandonment } \\
\text { 1970/1981-Restoration } \\
\text { 2003-Arc Collapse } \\
\text { 2007-Arc Rebuilt }\end{array}$ & $\begin{array}{c}\text { Archaeological Ruins remains + } \\
\text { Offices }+ \\
\text { Religious Art Museum. }\end{array}$ & 4334 \\
\hline $\begin{array}{l}\text { Compañía de Jesús } \\
\text { Convent }\end{array}$ & 1575 & 1673 & $\begin{array}{c}\text { 1749/1767 } \\
\text { San Javier Univ. } \\
\text { 19th Century-Private } \\
\text { House + Hotel Washington }\end{array}$ & $\begin{array}{c}\text { 1737-Fire } \\
\text { 1767-Expulsion } \\
\text { 1781-Fire } \\
\text { 1882-Earthquake }\end{array}$ & $\begin{array}{l}\text { Archaeological Ruins remains + } \\
\text { Private Houses + Hotel in } \\
\text { construction }\end{array}$ & 6044 \\
\hline Cathedral & 1524 & 1676 & - & 1943-Restoration & Cathedral in use & 3570 \\
\hline $\begin{array}{l}\text { Church of } \\
\text { San Felipe }\end{array}$ & - & 1685 & - & $\begin{array}{l}\text { 1737-Fire } \\
\text { 1913/1920-Rebuilt }\end{array}$ & Church in use & 227 \\
\hline $\begin{array}{l}\text { Church of } \\
\text { Santa Ana }\end{array}$ & 1568 & 1677 & - & $\begin{array}{c}\text { 1854-Fire } \\
\text { 1911-Restoration }\end{array}$ & Church in use & 1355 \\
\hline TOTAL & & & & & & 35,021 \\
\hline
\end{tabular}


Of the elements analyzed, we will focus on the development of the seven cases that have led to a notable value loss due to the disappearance of the monastic trace. We have left the three examples of continuity of use out of the analysis, which are also less relevant regarding the impact on the urban layout in terms of surface area (Figure 3).

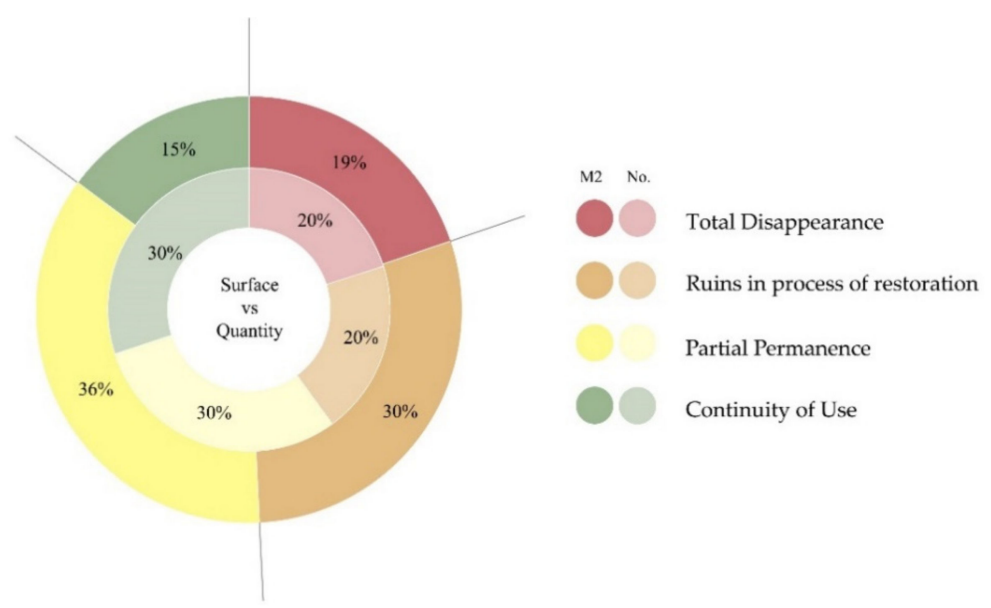

Figure 3. Comparative graph between the cases of study and their area measured based on the current plan of the Office of the Historic District (Oficina Casco Antiguo-OCA).

\subsection{Examples of Partial Permanence until Today (Only Churches in Use)}

\subsubsection{San Francisco Convent (Bolivar Palace or Panama Chancellery)}

The San Francisco Convent began its construction in 1573 and was abandoned after the looting following the pirate H. Morgan's occupation in 1671. In 1673, the royal order to transfer to the new city arrived, and the Franciscan order was assigned one of the best enclaves in front of the Bay of Panama, in the new settlement. The Franciscan convent managed to become one of the largest in the new city, in contrast to the previous location in Panamá Viejo. Instead of being at the center of the old settlement, it was far from the founding nucleus due to the indigenous evangelization policies that had characterized the order [16] (p. 744).

In the mid-18th century, after the large fires that occurred, the building fell into a state of ruin and progressive deterioration. Despite some restoration attempts, the Franciscan friars were forced to leave the convent in the early 19th century. This abandonment also occurred due to the measures that the Colombian government was taking just before the union of the isthmus with Gran Colombia, in line with confiscating religious buildings that did not have a sufficiently large number of monks, as was the case of the Franciscans. Therefore, the State, already independent from Spain in 1821, confiscated the building to turn it into an army barracks. At this time, some historical-political milestones took place in the former convent premises, the Amphictyonic Congress of Panama (1826) called by the liberator Simón Bolívar, giving it its current name to the Salón or Palacio Bolívar.

In addition to military or political uses, the building also was the "Hospital for Foreigners" before it moved to Ancón Hill, as well as different colleges and schools throughout the 20th century: Balboa National School (1892-1899) of the Piarist Fathers, La Salle/Javier School (1910-1952), San Agustín School (1953-1959), and the Bolívar Institute (1959-1999). The latter three had the support of the Jesuits, which shows that the building never lost its religious character, since the church also remained active throughout all these periods [17].

Entering the 21st century, new restoration works were carried out on the three existing pavilions built at the beginning of the 20th century, and there was a subsequent expansion with the new "Centennial Pavilion" (2000-2003) to transform the building for public administrative use as headquarters of the Ministry of Foreign Affairs or Chancellery of Panama. During this project, the main interior patio was redesigned as Libertadores Square, a covered space in homage to the political events 
that took place in this enclave. During such works, traces of the old convent were found, such as the Franciscan laundry and kitchen areas, representing the only present evidence of that original building.

Today, only the San Francisco Church remains from the entire original convent complex (Figure 4), the only piece to survive all changes of use. However, we must also mention that this icon of the colonial baroque has also gradually changed its character and heritage value due to successive restorations. In 1918, it was "restored and completely distorted" according to historian Ángel Rubio. This criticism adds to the claims of several Panamanian historians such as Narciso Garay and Rubén D. Carles, pointing out that "the restoration effort of our pious people has destroyed the facades of our temples, their pulpits and altars made of a single piece and carved so finely that they resemble rich goldwork, to be replaced by concrete facades, pulpits and altars, more modern and colorful, but less rich in art and splendor" [5].

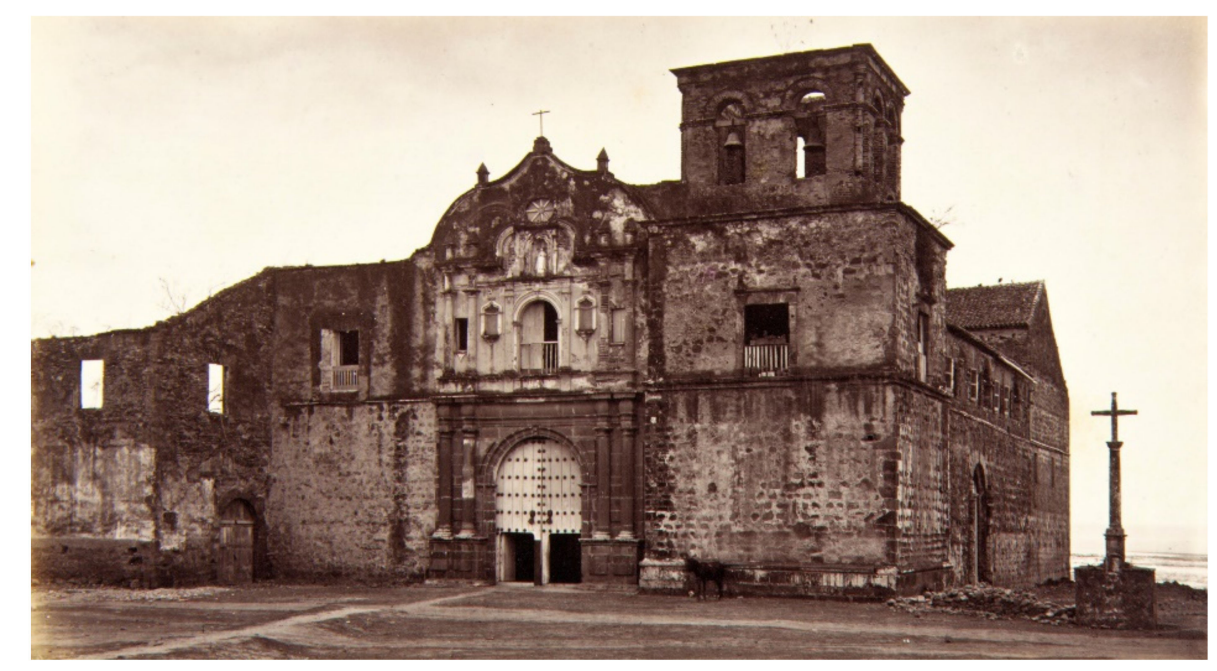

Figure 4. Church of San Francisco in 1875 by E. Muybridge [18].

As a heritage analysis, we can conclude that the predominant historical value of this monumental complex is more closely linked to its political character as the scene of momentous events such as the Isthmus Battalion (1823), the Amphictyonic Congress of Panama (1826), and the writing and signing of the first Constitution of the Republic (1904) than the monastic character with which it was conceived almost four centuries ago.

\subsubsection{Nuestra Señora de la Merced Convent and Church}

The Mercedarian Order was the first to settle and the last to leave the city of Panamá Viejo. Located on the outskirts, it managed to save a large part of the original structure after the attacks of the pirate Morgan.

In any case, they were assigned a block just in front of the new Puerta de Tierra of the city wall, that is, next to the main access to the new city. Then, the Mercedarians erected a small wooden building for the church and dormitories. As its previous location was practically intact, between 1720 and 1732 , the order focused all their efforts on rebuilding the church in image and likeness to the one in Panamá Viejo (bringing the material of the facade stone by stone). For this reason, this church is known as "that of the two cities", and it has endured to this day as one of the best-preserved churches in the area [17].

Like the other religious communities, the Mercedarians were expelled in 1861, resulting in the convent disappearing and the church closing. The temple remained intact, being designated as the Tabernacle of the Cathedral in 1875 (Figure 5), until the worship was gradually re-established. 


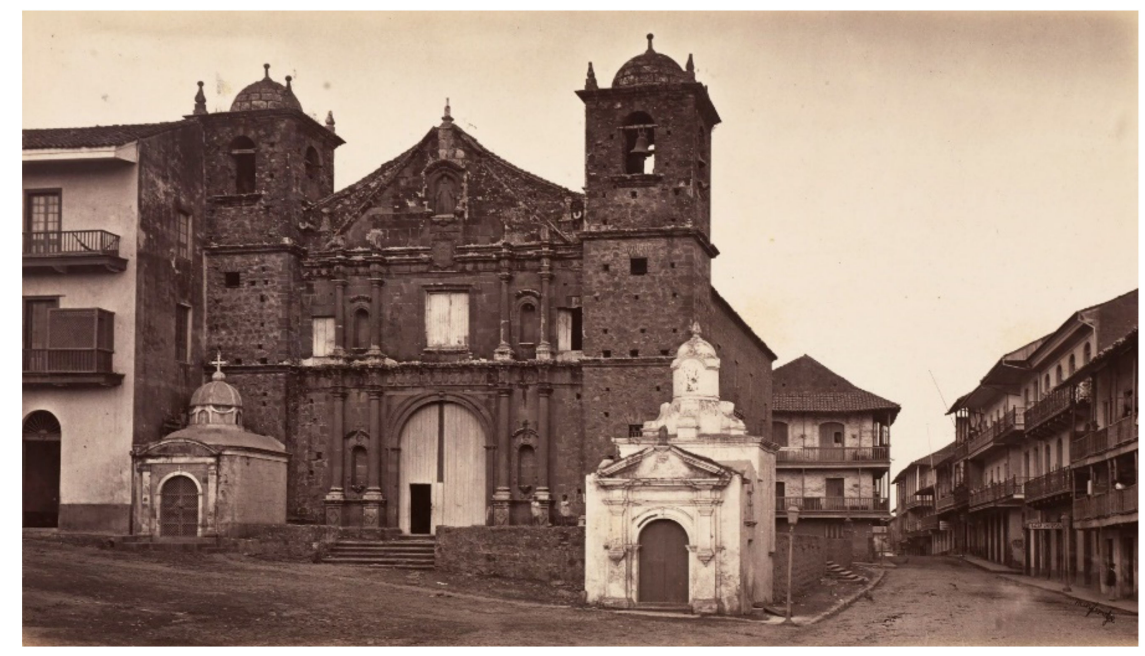

Figure 5. Church of the Merced in 1875 by E. Muybridge [19].

In 1963, several of its most outstanding architectural assets (choir and main altar) were lost in a fire and the restoration work had its deficiencies. In 1983, the order returned, carrying out several restorations in the building [20] that make it one of the most unique churches in the city, its facade being an example of both historical and artistic value.

\subsubsection{San José Convent (Today Golden Altarpiece Church)}

The Augustinian monks were among the last congregations to settle in Panama when they founded the San José Church and Convent in Panamá Viejo in 1610 [21]. Located outside the walls, it was practically unaffected by fires after the devastation of the pirate Morgan in 1671 and it remained intact.

With the transfer in 1673, the authorities decided to move it to a safer place, providing them with a complete block within the city walls, close to the Jesuit convent. It functioned normally and without major interruptions in its work until, in 1833, when the religious were expelled following the aforementioned decree promulgated by the new Colombian government. Due to the characteristics of the complex, it could have been used for other purposes, such as educational use. However, as there were nearby schools, it was auctioned and divided [22].

The church, which was left in ruins at that time, has managed to endure over time. In 1898, with the expulsion of the Spanish clergy from the Philippines, the Augustinian Recollects decided to return to Panama after several decades of plundering through the Concordat between the State and the Church ended in 1887. At that time, they raised their religious community again, restoring the original church that we know today (including the famous Golden Altarpiece). As a result of their return and the restoration, the Augustinian Order evolved to become one of the most active religious communities in the country, with other locations in cities such as Bocas del Toro, Río Abajo, and David [22].

\subsection{Examples of Disappearance of the Historical Urban Footprint of Monastic Elements}

\subsubsection{Monjas de la Concepción Convent (National Theater-Government Palace)}

The Monjas de la Concepción Convent has a singularity, which is that it was the seat of the only female religious congregation established in Panama during the colonial period. During that period, the original convent was located close to the founding nucleus of Panamá Viejo. As for the first convent located in Panamá Viejo, the remains of its church and cloister have managed to survive to this day in relatively good condition. This is probably due to the fact that their construction was later and more solid (mid-17th century), and due to the conservation process carried out [23]. Likewise, the fact that the complex was partially unfinished during the disaster of 1671 [24] (p. 19) may be the reason why it became the first religious building erected in the new Panama City on the same day the city was 
moved, a large part of the materials for the works had already been mobilized. Therefore, we will proceed to examine the convent once it was erected in the Historic District.

This convent was in use for almost two centuries until, due to the decree on the seizure of "dead hand goods" in the mid-19th century, the last nuns abandoned it in 1862. Later, it was temporally used as a hospital administered by the Sisters of Charity, and after as army barracks, which were renamed Barracks of the Nuns between 1880 and 1890.

In 1903, when the Republic of Panama was established, it was decided to build the National Theater. It was constructed in part of the property occupied by the Monjas de la Concepción Convent since the 18th (Figure 6). The lot had passed to the State after the expulsion of the nuns in 1862 and served as barracks. In early 1905, the colonial building was demolished and the new works began immediately, simultaneously starting the new National Theater, which occupies the northern half of the block, and the Government Palace [11] (pp. 202-203). With the demolition of this building, valuable architectural elements such as a tall tower were lost.

There are hypotheses such as that of Tejeira Davis [25] (pp. 12-14), that place the new buildings on the traces of the old convent. Specifically, the National Theater would be partially built on what were the orchards and the cloister of nuns, since other parts were outside the current built area and have disappeared. In fact, the same study reveals that before its demolition, the building itself was already used as a theater, thus anticipating the current use even before its disappearance, being called "Theater of the Nuns". The work of architect Gennaro N. Ruggieri and the successive restorations of the building to this day bear no relation to the original historical religious value.

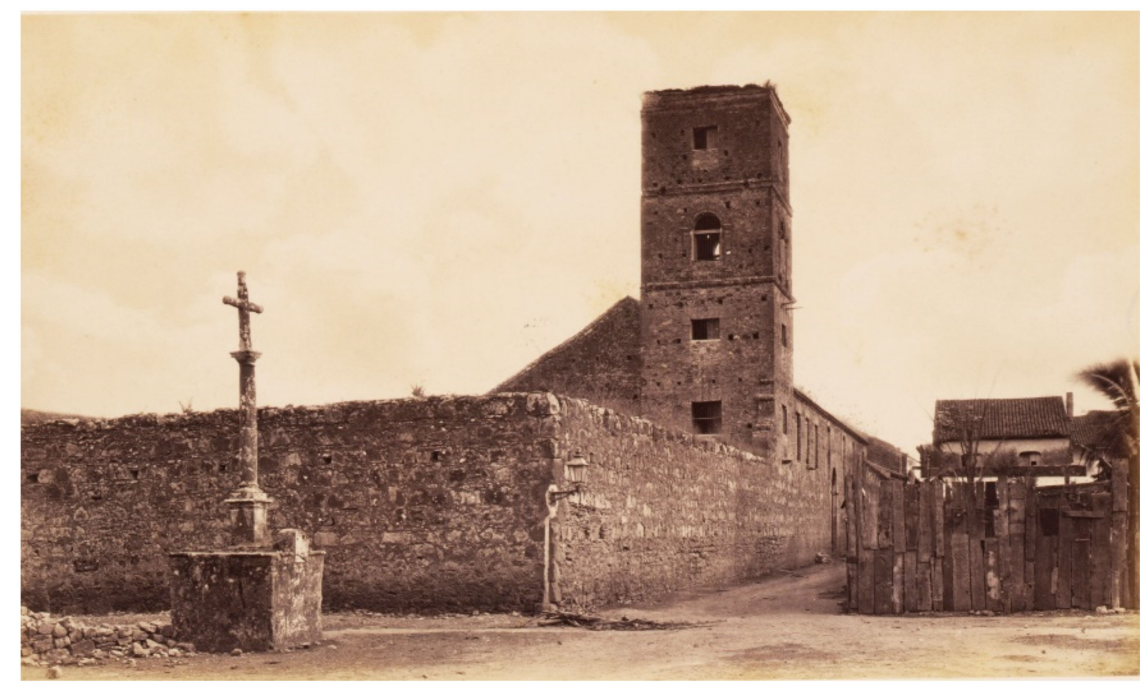

Figure 6. Ruins of the Monjas de la Concepción Convent in 1875 by E. Muybridge [26].

\subsubsection{San Juan de Dios Church and Hospital (Republic of Mexico School and Other Uses)}

The current ruins of the San Juan de Dios Church and Hospital in Panamá Viejo correspond to its second location within the city, since before moving it to the current location of its remains in 1585, it was run as Hospital San Sebastián. In 1628, the friars of the Order of San Juan de Dios (hence its name) arrived to administer it [27] (p. 69).

The residents of San Juan were also granted a large site to move the hospital to the new city in 1673, located next to the walls (between the Bulwark fortification of Barlovento and the "Postigo de San Juan de Dios"). We know little about the process endured by this new building until its closure in the 19th century. We can cite its resistance to the fires of the 18th century, being one of the few that survived, especially to the "Big Fire" of 1733 [12] (p. 33).

The complex was transformed in 1845 [28], but its deterioration began in the first third of the 20th century, when the church lost the original tower (Figure 7). At the present, the space formerly occupied 
by religious facilities is destined, on one hand, for educational use. Part of the building was converted into the Republic of Mexico School (Figure 7), which tried, to some extent, to recover the image of the pre-existing church. On the other hand, the rest of the premises were changed to commercial use. There is no trace of the tower or of what once was the convent.

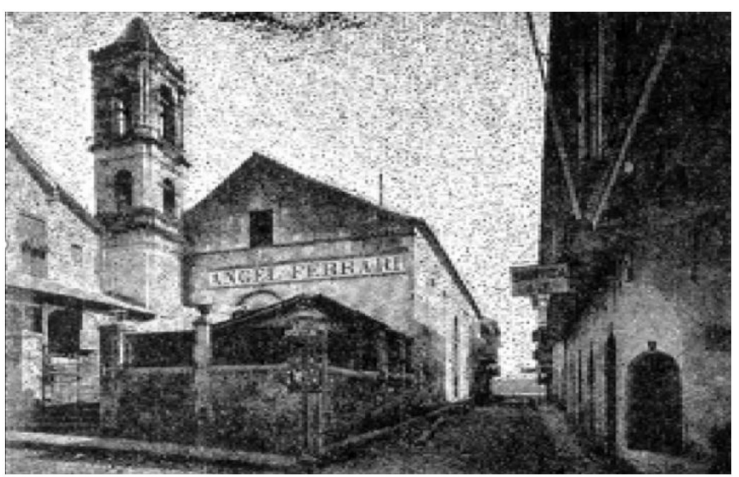

(a)

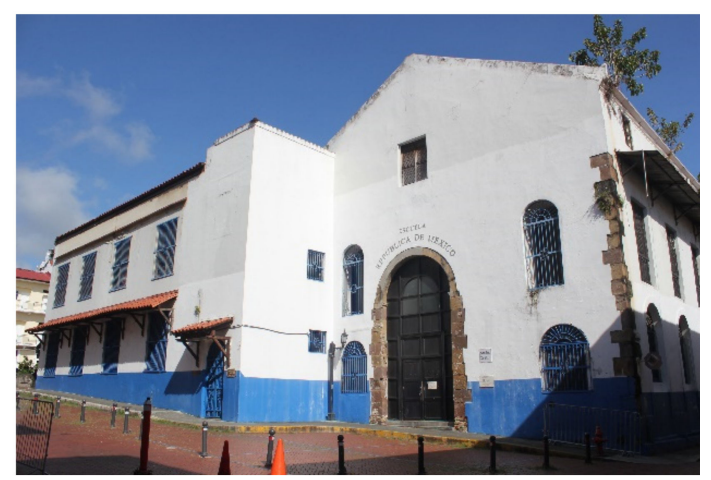

(b)

Figure 7. San Juan de Dios Hospital: (a) Church in 1888 with the original tower [28]; (b) Current school.

\subsection{Ruinous Remains in the Process of Restoration and Enhancement}

\subsubsection{Santo Domingo Convent (Archaeological Remains of "Flat Arch" and Museum of Religious Art)}

The Dominicans took longer to settle in Panamá Viejo than other orders, since it was not until 1571 that they founded what began as a church and rooms for the friars. However, in the transfer to the new city, they were among the first religious to establish their convent. By 1678, they had already built the Santo Domingo Church and Convent, together with San Francisco, representing the most monumental temples in Panama. The convent was affected by the fires of 1737 and 1756, in which the tower and its interiors collapsed. However, walls and arches remained standing (Figure 8), particularly the lowered arch, known as the "flat arch", that supported the choir of the church [5] (p. 158).

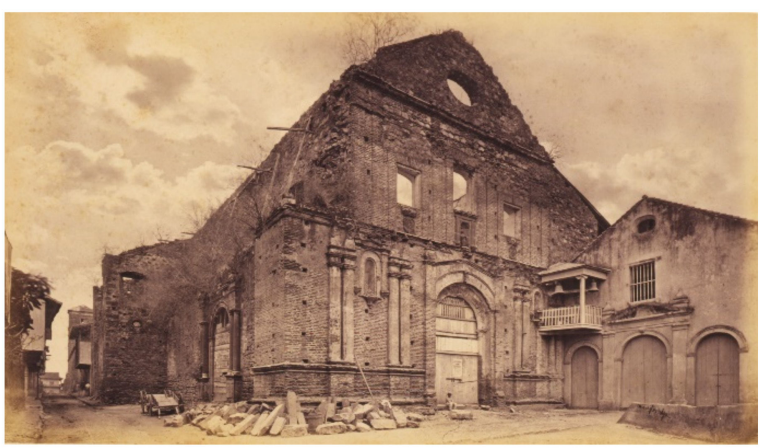

(a)

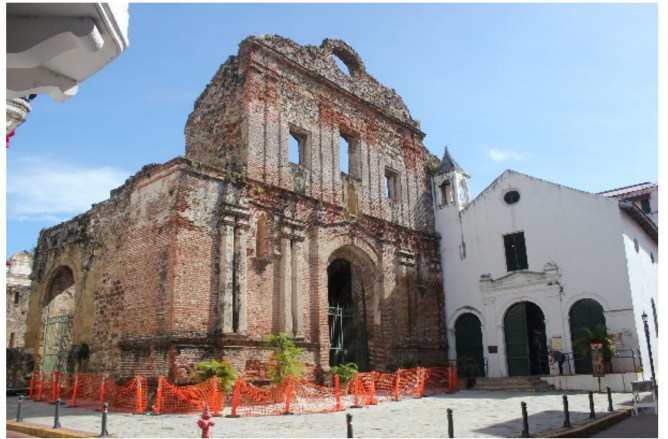

(b)

Figure 8. Ruins of the Santo Domingo Convent: (a) State in 1875 by E. Muybridge [29]; (b) Today.

In the early 19th century, the convent had only one friar and it ended up closing shortly after. After the Decree of 1857, the sale by public auction was authorized and this led to the fragmentation of the complex, which was transformed into houses and even small businesses [17]. Finally, in 1925, a Presidential Decree prohibited the transfer or demolition of what remained of the convent. 
The "flat arch" remained intact and showed its durability and strength after the events of the 18th century. During the Panama Canal negotiations, it served as an example of a catastrophe-resistant structure. The "flat arch" collapsed in 2003 and a reconstruction of the original was carried out between 2004 and 2007 [11] (p. 201).

The ruins of the convent now have a special role within the Historic District, declared as a First Orden monument, with an important artistic, historical, and monumental value. The existing buildings nowadays have public administrative uses related to heritage, as the headquarters of the National Directorate of Historical Heritage. In addition, what was the temporary chapel, built after the fire that destroyed the original temple, is used today as the Museum of Colonial Religious Art, which constitutes a paradigmatic example of the possible link between current and past uses.

\subsubsection{Compañía de Jesús Convent (Ruins in the Process of Tourism Adaptative Reuse)}

The Jesuit convent was founded in the same way as the previous case, later than the rest of the facilities of other religious orders. Together with the Monjas de la Concepción Convent, it was located near the Plaza Mayor in the noblest area of Panamá Viejo. This congregation had a long educational tradition and that is why they will always be linked to educational purposes.

When the transfer to the new city took place in 1673, the Jesuits barely had the capacity to obtain buildings of similar values to those that characterized their previous buildings in Panamá Viejo. The school and church structures, called San Javier School, were built using wood and were thus, destroyed in the fire of 1737. After this accident destroyed two-thirds of the city, in 1749, the convent was rebuilt as the first university in the country, the Royal and Pontifical University of San Javier, this time with a resistant masonry structure. However, it was not used long. Approximately two decades later (1767), King Carlos III decided to expel all the Jesuits from the Spanish dominions, leading the order into exile. A few years later, the fire of 1781 destroyed a large part of the complex, which remains in a ruinous state to this day [30] (p. 35).

After the events of the 18th century, and despite the poor general condition of the site, some of its buildings remained in use as a private residence or later as a hotel, the Hotel Washington, active between 1820-1840. In 1865, the complex was divided into five parts and sold to individuals by public auction. It had various uses, such as stables, sheds and it even contained two houses. The main chapel ended up accommodating a two-story house. The first synagogue of the Kol Shearith Israel Congregation of Panama functioned in this house between 1918 and 1935 [31].

In the 1970-1980s, plans and tools for its protection began to be designed in the country, such as Law 91 of 1976 for National Protection, creating the category of Historical Monumental Complex $(\mathrm{CMH})$, thus cataloguing the Historic District of the city and delimiting the protected sector and its basic conservation standards. We can also mention Law 14 of 1982, which further detailed the measures for the custody, conservation, and administration of Historical Heritage [30] (p. 38).

In this context (1979), the central courtyard, the church and the sacristy were acquired by the administration of the Panamanian Institute of Tourism (IPAT), known today as the Panama Tourism Authority (ATP), which was in charge of carrying out restoration and conservation interventions at that time (Figure 9). The cloister, on the other hand, was sold to private owners. Currently, there is a project led by a private promoter for the reuse of the entire complex under the slogan "Hotel La Compañía" for a mixed-use space for a hotel, restaurants, and commercial premises. 


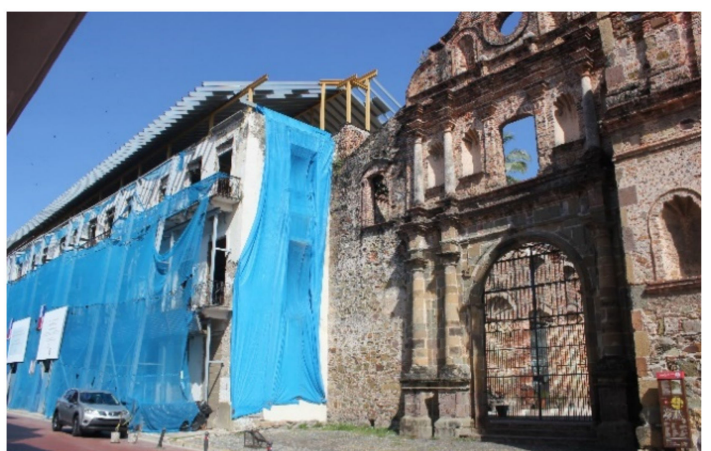

(a)

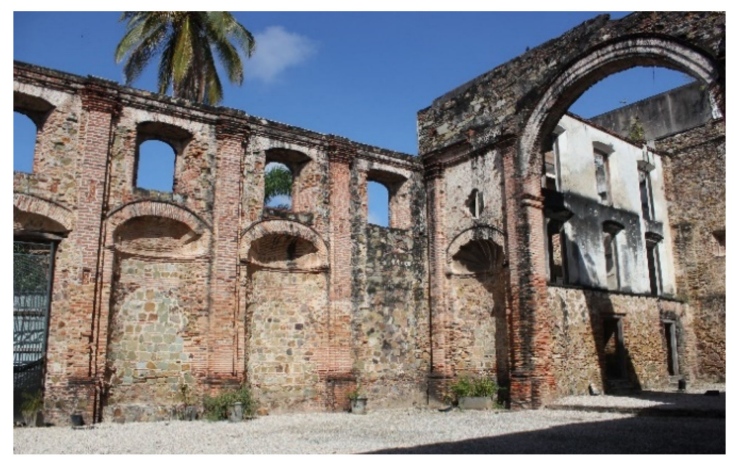

(b)

Figure 9. Ruins of the Compañía de Jesús and Hotel under construction: (a) Exterior Facade; (b) Interior of the original Church.

As we have mentioned previously, in the Historic District Standards Manual, buildings are classified into four orders of protection. In this case, all the buildings derived from the Jesuit convent (both public and private) managed to achieve maximum protection or first order, except for the building previously used for the Javeriana University, which was classified as second order. This fact gives us information about the heritage loss: on the one hand, the lack of understanding of the convent as a single complex, built for the same purpose (educational-religious) and, on the other hand, the different intervention or conservation criteria for the separated pieces of the building, which will probably increase the architectural and urban value loss of what was once the Compañía de Jesús in Panama.

\section{Conclusions}

After developing the case studies, we proceeded to draw conclusions from the research, classifying them by themes that, schematically, try to be illustrative. This analysis highlights the weaknesses and strengths of the religious architecture evolution process in Panama City from the perspective of urbanism, history of architecture, and heritage conservation.

\subsection{Conservation through the Continuity of Use}

From the case studies related to conservation through the continuity of use, the San Francisco Convent has the most altered image. It had multiple uses during de 19th century, the most important as the headquarters of the Amphictyonic Congress of Panama (1826). The church went through very much criticized restoration works at the beginning of the 20th century, that are only known to academics and experts. The massive construction of the new wing distorted the structure and, during this process, the archaeological remains of the convent premises were brought to light. These buildings nowadays have more of a political character, appropriate to their use. Unfortunately, the buildings are seen as isolated elements in the history of architecture. The archaeological remains, the many transformations of use and the restoration works must be used to interpret the convent and experience the complex as a whole.

For the San José Convent, the return of the Augustinian order in 1898 became a very important milestone for its conservation, because it helped to maintain its religious use. The case of the Mercedarian convent is quite different. La Merced, especially its church, preserves its important historic and artistic value. Moreover, it has recovered part of the original plot of the cloister and transformed it into a museum and administrative offices. The church is a permanent link between Panamá Viejo and the Historic District. It represents one of the reasons why the World Heritage Property includes both monumental complexes, because it provides "a measure of material continuity between the two components" [2].

As a result of the analysis of these three cases, San Francisco represents the most difficult convent to interpret, followed by San José and La Merced. The latter with a more comprehensive and coherent 
structure. One can argue that, in the case of San Francisco, the mixture of uses complicated the interpretation. In the case of San José, the division of the plot did not help its interpretation. This leaves La Merced as one of the best examples of case studies. The churches of these three convents are still in constant use.

\subsection{Historical Attributes Missing}

Firstly, it is necessary to emphasize the negative aspects that are extracted from the historical review carried out in the case studies where the historical attributes are missing. Models of colonial religious architecture, such as the Monjas de la Concepción Convent and the San Juan de Dios Church and Hospital, have disappeared, mostly due to confiscations during the 19th century. Therefore, certain historical, architectural, religious, and cultural values have disappeared. It is true that these attributes no longer existed at the time of declaring the Historic District of Panama a UNESCO World Heritage Site. This was not an obstacle to such declaration due to its Outstanding Universal Value in terms of urban layout, dimension, and distribution of lots in the terrain, and architecture from the 19th and 20th centuries, attributes that currently represent what the city is.

However, this research tries to enhance the value that this specific monastic typology meant for the city and which has been disfigured to the point that its contribution to the global historical identity has been lost or diluted to some extent. We can imagine what that urban landscape would be like if the remaining buildings mentioned in the text had lasted to this day. The Historic District of Panama probably would have and added attribute to its landscape, as a city surrounded by towers, including the church bell towers of the convents of San Juan de Dios and Monjas de la Concepción.

An important recommendation would be to carry out interpretation and dissemination projects, mainly in cases where the attributes are not visually appreciated, such as in the Monjas de la Concepción Convent (National Theater and Government Palace) and the San Juan de Dios Church and Hospital (Republic of Mexico School). In the same way, in the long term, one can think of a three-dimensional representation of each of the important periods of the city with the aim of continuing the study of the mark left by the colonial religious architecture typology, taking into account its monumentality and scale within the urban footprint of the Historic District of Panama City.

\subsection{Architectural Heritage Reuse Processes}

\subsubsection{Influence of Legislation}

As is the case in all historic cities, the risks of destruction of heritage values are very high as long as there is not a sufficiently strong regulatory framework to prevent or restrict negative interventions in buildings. The loss of heritage elements of great value that we have brought to light in this work can be attributed, to a certain degree, to the absence of such a framework until relatively recently. It was not until the 20th century that new and effective tools arrived that stopped the destruction of heritage to some extent. In the case of Panama, there have been attempts to protect specific monuments since 1908 and it was specifically in 1976 when Law No. 91 was passed, "by which the Historic Monumental Complexes of Panamá Viejo, Portobelo and the Historic District of Panama City are regulated". This is when a real concern for the conservation of historical heritage begins to emerge.

It is important to highlight the imperative need for a good use of these legislation tools. Events such as the division of the former Compañía de Jesús complex in private and public ownership, probably occurred because the legislation was recent and the tendencies at that time were to preserve heritage through tourism. Regulation and control are essential, but unfortunately, there is no guarantee of their contribution to the adequate conservation of historical heritage.

Regarding the current legislation, the 2004 Historic District Standards Manual was correct at the time. It protects aspects such as seniority through the aforementioned first, second, third, and fourth order classification. At the same time, it preserves heights and points out the need to maintain the "environmental value" of the site. One detail that was not taken into account when writing this manual 
is that this "environmental value" cannot be preserved only by maintaining heights, the volume must also be taken into account. There are several projects carried out within the Historic District and in its buffer zone that, despite meeting the required height, have a massive volume that disrupts the harmony of the complex and affects the Outstanding Universal Value of the cultural property.

Projects that concern the mentioned continuity of use, such as the already mentioned case of the Franciscan convent, and the archaeological remains, like Compañía de Jesús, are affected or might be affected by these issues. The Compañía de Jesús, specifically the area of the former cloister (the private part of the property), will begin the construction of a hotel that will probably maximize its volume. Furthermore, it will possibly not be long until the hotel decides to open access to the patio and church of the former convent which might lead to an unsupervised intervention.

\subsubsection{Tendency to Reuse the Most Relevant Monumental Heritage for Institutional Use}

Theory and principles of conservation tend to approve the change in the use of a building if it is well managed and if that change does not have negative effects on its surrounding. The Venice Charter [32] mentions that "the conservation of monuments is always facilitated by making use of them for some socially useful purpose". The more recent Principles of Valetta [33] outline the problem of gentrification, which is not covered in our research, and explains that "New activities must therefore be carefully managed to avoid secondary negative effects such as transport conflicts or traffic congestion".

Public administrations tend to take advantage of and reuse the most unique heritage of historic cities for their institutional development. This represents an important option for the protection of architectural heritage, and it is a fact that occurs, according to our clear perception, in all cities. One can cite, for example, the case of the city of Seville, in Spain, where the public administration after the political change marked by the approval of the Constitution and the emergence of autonomies in the 1980s reuses a large part of the city's historic buildings for its new institutional headquarters [15].

Through the article, we have mentioned several examples of change of use. The Santo Domingo Convent (National Directorate of Historical Heritage and Museum) represents one of the best examples of the case studies. It seems to us that the reorientation towards administrative use (and cultural use in this case) is not a poor transformation or reuse alternative for these properties. Moreover, the public restoration works are managed with a special prudence and enthusiasm from the entities and are aimed at the preservation of the values of those buildings, thus avoiding their eventual degeneration.

An important recommendation would be to strengthen the legislative framework and monitor the future adaptive reuse projects to maintain the values and attributes of the pre-existing building, as well as its surroundings in a wider and broader context.

\subsubsection{Private Initiative as Asset Reactivation}

It is essential to develop architectural restoration and urban reactivation projects to avoid deterioration and loss of heritage. However, this task cannot be the sole responsibility of public administrations given that, on occasions, either due to lack of institutional action or even due to lack of funds, many buildings end up relegated to abandonment, thus requiring the help of the private sector. We have not cited the case of the "Revive the Historic District" project [34], as it does not have a specific relationship with the analyzed typology. Instead, it is related to an urban and social approach. However, it seems appropriate to cite this project that began linked to this new interest in the late 20th century in the conservation and restoration of heritage, promoted by individuals. Public administration subsequently joined in support, being one of the determining figures to be able to carry out the proposal before UNESCO to classify the Historic District as a World Heritage Site. In this project, actions are divided into various points: reviving quality, community, pride, architecture, and tourism. The latter is related to the next section. 


\subsubsection{New Emerging Uses (in Particular, Tourism Use)}

As mentioned earlier, even though new uses can be adapted to built heritage, there is still a risk if the process is not managed correctly. The priority in the interventions might not always be the conservation and the interpretation of the buildings. Sometimes other factors have an influence, such as profitability, especially if the project is promoted by the private sector. Therefore, we must emphasize the responsibility of the competent authority when supervising the interventions in the built heritage. The authorities have to ensure that the original value will not be damaged or lost, that the restoration is distinguishable from the pre-existing building, that it is reversible to the extent possible, and that it respects the urban and environmental surroundings, among other recommendations of the International Restoration Charters.

Such a warning does not contradict the fact that we consider the reuse of historical buildings to be positive, providing them with new contemporary and emerging uses, such as those related to tourism, which has been on the rise in recent decades. We consciously finished our compilation and analysis of significant elements of religious architecture in the present study precisely with the Compañía de Jesús project. This case study shows an example of adaptative reuse that in our opinion should be reviewed carefully by authorities. It can be a positive or negative example, depending on the correct use of the legislative framework and the respect of its values and attributes

Author Contributions: Conceptualization, A.C.H.; methodology, A.C.H.; validation, S.A.D.; formal analysis, A.C.H., S.A.D.; investigation, A.C.H., S.A.D.; writing—original draft preparation, A.C.H.; writing-review and editing, A.C.H., S.A.D.; supervision, S.A.D. Both authors have read and agreed to the published version of the manuscript.

Funding: This research received no external funding.

Acknowledgments: The authors gratefully acknowledge the Smithsonian American Art Museum for let all historical images free of copyright restrictions online and the Sistema Nacional de Investigación (SNI) de la Secretaría Nacional de Ciencia, Tecnología e Innovación (SENACYT) de Panamá.

Conflicts of Interest: The authors declare no conflict of interest.

\section{References}

1. Cooke, R.; Sánchez, L.A. Panamá indígena: 1501-1550. In Nueva Historia General de Panamá; Castillero Calvo, A., Ed.; Comisión 500 Años de Fundación de la Ciudad de Panamá, Phoenix Design Aid A/S: Randers, Denmark, 2019; Volume 1, pp. 115-160.

2. UNESCO World Heritage. Retrospective Statement of Universal Value. Archaeological Site of Panamá Viejo and Historic District of Panamá, 1997-2003. In Proceedings of the 37th Session of Convention Concerning the Protection of the World Cultural and Natural heritage, Phnom Penh, Cambodia, 16-27 June 2013. Available online: https://whc.unesco.org/archive/2013/whc13-37com-8Eadd-en.pdf (accessed on 22 August 2020).

3. Ganau, J. Los espacios religiosos y militares en la transformación de las ciudades catalanas del siglo XIX. In XIII Coloquio Internacional de Geocrítica: El Control del Espacio y Los Espacios de Control; Universitat de Barcelona: Barcelona, España, 2014; pp. 1-25.

4. López Guzmán, R. Historia del arte en Iberoamérica y Filipinas; Editorial Universidad de Granada: Granada, España, 2003.

5. Gutiérrez, S.A. Arquitectura Panameña: Descripción e Historia; Autoridad del Canal de Panamá: Panama City, Panama, 1999.

6. Osorio Ugarte, K. Los atributos del Valor Universal Excepcional de una propiedad considerada Patrimonio Mundial. El caso del Sitio Arqueológico de Panamá Viejo y Distrito Histórico de Panamá. Canto Rodado 2012, 7, 1-27.

7. De García Paredes, L.E. Mudanza, traslado y reconstrucción de la ciudad de Panamá en 1673. Rev. Cult. Lotería 1963, 93, 64-81.

8. Arroyo Duarte, S. Transformaciones en el Sitio Arqueológico de Panamá Viejo: El Ejemplo de Las Casas Reales. Ph.D. Thesis, Universitat Politècnica de València, València, Spain, 2016. Avalaible online: https: //riunet.upv.es/handle/10251/68508 (accessed on 22 August 2020). 
9. Castillero Calvo, A. Nueva Historia General de Panamá; Seis tomos, Comisión 500 Años de Fundación de la Ciudad de Panamá; Phoenix Design Aid A/S: Panama City, Panama, 2019; Volume 1, p. 215.

10. Tejeira Davis, E. Panamá: El Casco Antiguo y la Dinámica de Sus Transformaciones; Oficina del Casco Antiguo: Panama City, Panama, 2013.

11. Tejeira Davis, E. Panamá. Guía de Arquitectura y Paisaje; Instituto Panameño de Turismo y Junta de Andalucía: Sevilla, España, 2007.

12. Tejeira Davis, E.; Spadadora Gálvez, V. El Casco Antiguo de la ciudad de Panamá; Oficina del Casco Antiguo de Panamá, CiudadCity: Panama City, Panama, 2001.

13. Cubero-Hernández, A.; Pérez Cano, M.T. Permanence, Adaptation or Reuse: Transformations in the convents of the city of Seville. Open Eng. 2016, 6, 281-290. [CrossRef]

14. Pérez Cano, M.T. Patrimonio y Ciudad. El Sistema de Conventos de Clausura en el Centro Histórico de Sevilla: Génesis, Diagnóstico y Propuesta de Intervención Para su Recuperación Urbanística; Universidad de Sevilla y Fundación FOCUS-Abengoa: Sevilla, Spain, 1996.

15. Cubero-Hernández, A. El Proceso de Restauración del Patrimonio Histórico Inmueble Andaluz en los Últimos 30 Años, Criterios de Intervención y Protección del Patrimonio a Través de 100 Edificios de Sevilla. Master's Thesis, University of Seville, Seville, Spain, 2015. Available online: https://idus.us.es/handle/11441/43397 (accessed on 22 August 2020).

16. Linero Baroni, M.; Meza Suinaga, B. Conjunto Conventual San Francisco, Panamá Viejo, Panamá (1573-1671). In XII Congreso Latinoamericano de Patología de la Construcción y XIV Congreso de Control de Calidad en la Construcción CONPAT; Cartagena de Indias: Indias, Colombia, 2013; pp. 741-750.

17. Tribaldos, W. Reseñas Históricas Sobre Cada una de las Iglesias y Restos Arqueológicos Conventuales. La Prensa-Casco Antiguo. 2015. Available online: https://larutadebalboa.wixsite.com/casco/ (accessed on 22 August 2020).

18. Smithsonian American Art Museum. Available online: https://americanart.si.edu/artwork/church-sanfrancisco-panama-41513 (accessed on 22 August 2020).

19. Smithsonian American Art Museum. Available online: https://americanart.si.edu/artwork/church-mercedpanama-38456 (accessed on 22 August 2020).

20. Durán, F.; Yuste, F.J. Estudios y proyecto de consolidación estructural para la restauración de la Iglesia de la Merced en el Casco Antiguo de ciudad de Panamá. In Congreso Latinoamericano Rehabend; Santander: Valencia, España, 2014.

21. Sosa, J.B. Panamá la Vieja; Facsímile de la Primera Edición; Imprenta Nacional: Panama City, Panama, 1919; pp. 67-74.

22. Ayechu, B. Los Agustinos Recoletos en Panamá. Vicaría de la Orden de Agustinos Recoletos. 2000. Available online: https://www.oocities.org/vicariaoar/ (accessed on 22 August 2020).

23. Suárez Silva, L. Convento de las Monjas de la Inmaculada Concepción. Una Propuesta de formación. Canto Rodado 2013, 8, 1-16.

24. Carles, R.D. 220 Años del Periodo Colonial en Panamá; Taller de Artes Gráficas de la Escuela de Artes y Oficios "Melchor Lasso de la Vega": Panama City, Panama, 1969.

25. Tejeira Davis, E. El Teatro Nacional. La Historia de un Ícono Cultural; Instituto Nacional de Cultura de Panamá: Panama City, Panama, 2008.

26. Smithsonian American Art Museum. Available online: https://americanart.si.edu/artwork/ruins-convent-lasmonjas-panama-38454 (accessed on 22 August 2020).

27. Scholkmann, B.; Schreg, R.; Kottmann, A.; Zeichka, A. El Hospital San Juan de Dios, Panamá Viejo. Canto Rodado 2006, 1, 65-83.

28. Rubio, A. La Ciudad de Panamá; Autoridad del Canal de Panamá: Panama City, Panama, 1999.

29. Smithsonian American Art Museum. Available online: https://americanart.si.edu/artwork/ruins-church-sandomingo-panama-38452 (accessed on 22 August 2020).

30. Cid, P.; Cardoze, B. Historia constructiva del Complejo Monástico de la Compañía de Jesús en el Casco Antiguo de Panamá y análisis de su tutela. Investig. y Pensam. Crítico IPC 2018, 6, 30-51. [CrossRef]

31. Arias Calderón, R. Alberto Motta y Kol Shearith en Panamá; El Panamá América: Panama City, Panama, 2006.

32. International Charter for the Conservation and Restoration of Monuments and Sites (The Venice Charter). 1964. Available online: https://www.icomos.org/en/resources/charters-and-texts (accessed on 22 August 2020). 
33. The Valletta Principles for the Safeguarding and Management of Historic Cities, Towns and Urban Areas. 2011. Available online: https://www.icomos.org/en/resources/charters-and-texts (accessed on 22 August 2020).

34. Espino, A.; Young, D.; Durán, F. El Patrimonio Arquitectónico y la Restauración en la ciudad de Panamá. Rev. Arquit. 2007, 9, 38-47.

Publisher's Note: MDPI stays neutral with regard to jurisdictional claims in published maps and institutional affiliations.

(C) 2020 by the authors. Licensee MDPI, Basel, Switzerland. This article is an open access article distributed under the terms and conditions of the Creative Commons Attribution (CC BY) license (http://creativecommons.org/licenses/by/4.0/). 